Tezel A., Koskela L., and Aziz Z. (2017). "Lean Construction in Small-Medium Sized Enterprises (SMEs): an Exploration of the Highways Supply Chain.” In: LC3 2017 Volume II - Proceedings of the 25th Annual Conference of the International Group for Lean Construction (IGLC), Walsh, K., Sacks, R., Brilakis, I. (eds.), Heraklion, Greece, pp. 845-851. DOI: https://doi.org/10.24928/2017/0328

\title{
LEAN CONSTRUCTION IN SMALL-MEDIUM SIZED ENTERPRISES (SMES): AN EXPLORATION OF THE HIGHWAYS SUPPLY CHAIN
}

\author{
Algan Tezel ${ }^{1}$, Lauri Koskela ${ }^{2}$, and Zeeshan Aziz $^{3}$
}

\begin{abstract}
Lean Construction (LC) is under the spotlight to improve the overall performance of civil construction projects in England. A strategic target of public clients is to effectively extend the current LC efforts, which have been mainly led by large companies to date, across small-medium sized enterprises (SMEs). This paper presents a summary of the initial findings of a research effort aimed at understanding the current condition of and future directions for LC at the SMEs in England's highways supply chain.

The research comprises of 20 interviews with senior managers, of which the initial findings were summarized in this paper, and a comprehensive survey study with 110 responses across the highways supply chain. 31 points for the current condition and 40 action items for the future of LC in the highways SMEs were presented and discussed.
\end{abstract}

Keywords: Lean construction, SMEs, highways, civil, deployment, implementation

\section{INTRODUCTION}

Lean Construction (LC) has been under the spotlight to achieve a better value for investment and an improved performance in civil projects in England since the late 2000s (Drysdale 2013). Practical factors like soaring asset delivery and operations costs, Government's budget cuts and a general dissatisfaction with the services are the main causes of this attention.

In the highways sector specifically, LC has actively been championed by Highways England (HE), the main public client responsible for the delivery and operation of England's strategic highways network. HE promotes LC through engagement and contractual configurations with some large-sized main contractors (Tier 1s) and some specialised sub-contractors operating in key delivery areas like soil works, paving/surfacing or traffic management (large Tier 2s). Those large Tier 2s are almost on par with the Tier $1 \mathrm{~s}$ in terms of their annual turnovers and employee numbers.

HE prefers to use prime contracting with the Tier $1 \mathrm{~s}$ as its project delivery method. In that contractual configuration, a small number of Tier 1s form long-term partnerships with $\mathrm{HE}$ and the large Tier 2s for the delivery of a series of projects. HE commonly imposes a cap contract price, from which deviations in the form of price overruns or savings are shared between the Tier $1 \mathrm{~s}$ and HE to supposedly incentivise the Tier $1 \mathrm{~s}$ to make operational cost savings and to encourage the deployment of LC. Alongside this, HE is

\footnotetext{
Research Fellow, School of Art, Design and Architecture, University of Huddersfield, Huddersfield, UK, a.tezel@hud.ac.uk

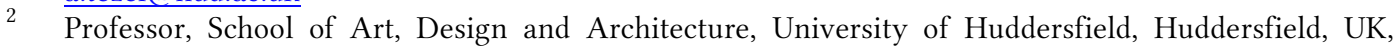
l.koskela@hud.ac.uk

3 Senior Lecturer, School of the Built Environment, University of Salford, Salford, UK, Z.Aziz@salford.ac.uk
} 
contractually imposing the use of some LC techniques like the Last Planner System or Visual Management in its contracts with the Tier 1s. Also, the Tier 1s and large Tier 2s are monitored by HE for their LC maturity. This active LC agenda led to the entrance of many consultants into the sector. Those consultants work collaboratively with the Tier $1 \mathrm{~s}$ and large Tier 2s and offer LC trainings for the supply chain.

Despite constituting the largest group in the supply chain (Morton and Ross 2008), the engagement with small and medium sized enterprises (SMEs) for LC has been limited to date. In this equation, the SMEs have been chosen by the Tier 1s, often for short terms on the minimum price basis with fixed-priced contracts. Also, the SMEs have been rarely in direct contact with HE for their LC or other process improvement efforts, which are mostly shaped and directed by their Tier 1 clients. Due to the nature of work, the SMEs have to execute their on-site operations in short working windows to avoid extended traffic disruptions. Given this context, one of the strategic targets of HE is to effectively disseminate LC across the whole highways supply chain, primarily including the SMEs. This paper will present a summary of the initial findings of a comprehensive research project aimed at understanding the current condition of and future directions for LC in the SMEs in England's highways supply chain.

\section{LITERATURE REVIEW}

\subsection{Lean Construction Deployment}

LC deployments can be categorised into three levels with increasing degree of sophistication (Green and May 2005; Ogunbiyi et al. 2014); (1) process based LC deployment efforts to reduce waste, variability, information deficiencies and so on through some specific LC techniques, (2) arrangements to eliminate adversarial relations and to increase integration in the supply chain, and (3) a strategic change in the overall project governance towards the Integrated Project Delivery (IPD).

Most of the criticism for the current LC discussions is based on the assertion that they are way too much process and LC techniques focused, largely overlooking the macro factors like the industry's business and economic context, market dynamics and its overall

governance (Green 1999; Barros Neto and Alves 2007; Alves et al. 2012). Therefore, while conducting a LC deployment research, beyond some specific LC techniques or mantras, it is necessary to take the overall industry and sector context, and project governance structure into account.

\subsection{Lean Construction and SMEs}

As for the LC deployments in smaller-sized construction companies, some of the general arguments have been that (1) SMEs are more prone to variations in the economy; therefore, they do not have spare resources to invest in innovation (Alves et al. 2009, (2) the common lack of trust between SMEs and their larger clients as a hindering factor for partnering for LC (Briscoe et al. 2001), (3) competent LC deployments should integrate SMEs into the process, reducing the transaction costs of all parties; not only large contractors' (Miller et al. 2002), (4) a general lack of belief that there are mutual benefits in supply chain integration practices and other business improvement initiatives like LC (Dainty et al. 2001), and (5) the need for large clients' active support in terms of know-how and resources to develop capabilities in innovative approaches in SMEs (Ferng and Price 2005).

The exploration of LC in SMEs is limited in construction. The issue has been mainly discussed from the innovation and supply chain integration perspectives. Beyond generic 
remarks, the lack of sector-specific analyses (i.e. highways, rail, building, energy etc.) of LC in SMEs is even more salient, which presents one of the main justifications of this paper.

\section{RESEARCH DESIGN}

A mixed-research approach involving interviews and a comprehensive survey was used to explore two research questions:

1. What is the current LC condition in the SMEs in England's highways supply chain?

2. What should be the way-forward to disseminate LC across the SMEs in England's highways supply chain?

Following a literature review, 20 senior managers (4 from HE, 5 from the Tier 1s, 4 from the large Tier 2s, 7 from the SMEs) were interviewed face-to-face for circa 45 minutes between December 2015-May 2016. Companies with less than 50 million GB $£$ annual turnover were considered as SMEs. The interviewees were identified through HE and personal contacts.

After the literature review and analysis of the interviews, 31 points for the current LC condition in the SMEs and 40 actions for the way-forward were identified. To validate and rank the importance of the findings, the identified points and actions were turned into Likert-scale questions on a survey of 98 questions and distributed among managers across the supply chain. HE's database was used to pinpoint the relevant managers, who are experienced in both the SMEs' business context and the current LC efforts in the supply chain. Of the outgoing 289 surveys, 110 responses were collected between June - October 2016 with $38 \%$ response ratio. The research process can be seen in Figure 1. The analysis and write-up of the survey findings are currently underway. A summary of the interview findings outlining the current condition of and future directions for LC in the highways SMEs will be presented in the subsequent sections from the process, project delivery, training and project governance perspectives.

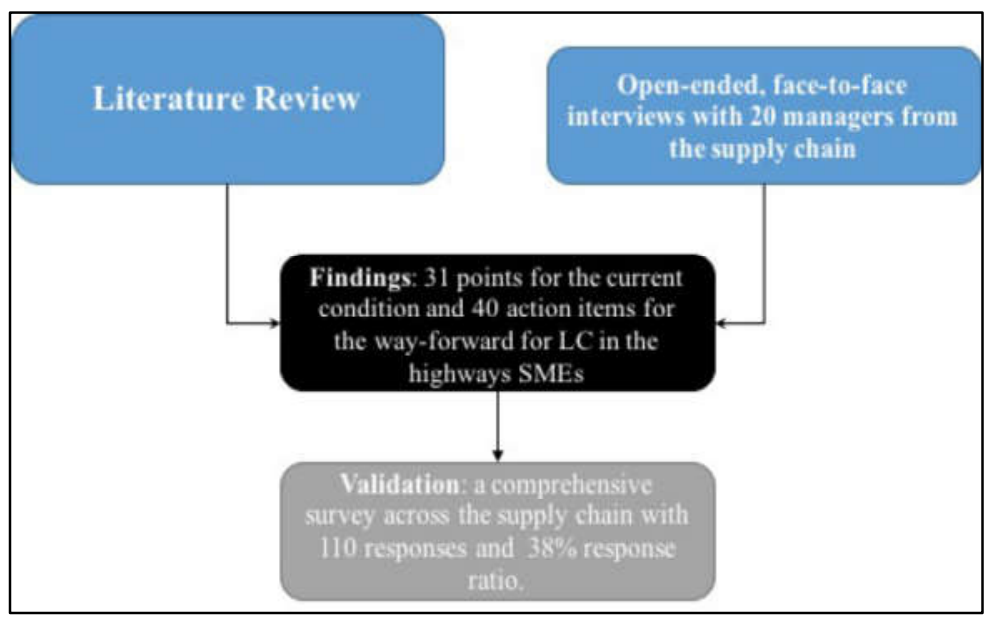

Figure 1: The research process 
Lean Construction in Small-Medium Sized Enterprises (SMEs): an Exploration of the Highways Supply Chain

\section{FINDINGS}

\subsection{Current Condition of LC in the SMEs}

As for the current condition of LC in the highways SMEs (for the first research question), as shown in Table 1, the interview findings were classified into four groups; process, delivery, training and project governance.

\section{Table 1: Current condition of LC in the SMEs}

\begin{tabular}{|c|c|c|c|}
\hline Process & Delivery & Training & Project Governance \\
\hline $\begin{array}{l}\text { Short-working windows on site } \\
\text { hamper LC improvement efforts }\end{array}$ & $\begin{array}{l}\text { LC deployment is not an } \\
\text { important parameter for the } \\
\text { SMEs to win future contracts }\end{array}$ & $\begin{array}{l}\text { Current LC training mechanism } \\
\text { just cover basic LC concepts }\end{array}$ & $\begin{array}{l}\text { Focus of HE for LC has been } \\
\text { mostly on the Tier } 1 \mathrm{~s} \text { to date }\end{array}$ \\
\hline $\begin{array}{l}\text { Due to lack of a complete systems } \\
\text { thinking, some improvements made } \\
\text { by an SME can put extra workload } \\
\text { or pressure on others }\end{array}$ & $\begin{array}{l}\text { SMEs generally start working on } \\
\text { short notice without much earlier } \\
\text { preparation }\end{array}$ & $\begin{array}{l}\text { SMEs generally do not have } \\
\text { internal LC training mechanisms }\end{array}$ & $\begin{array}{l}\text { Clients' drive is the main LC } \\
\text { motivation for the SMEs }\end{array}$ \\
\hline $\begin{array}{l}\text { Application of some specific LC } \\
\text { techniques has not been } \\
\text { standardized enough }\end{array}$ & $\begin{array}{l}\text { Conventional unit price or lump } \\
\text { sum contracts do not incentivize } \\
\text { the SMEs much for LC }\end{array}$ & $\begin{array}{l}\text { External training mechanism run } \\
\text { by consultants and the Tier } 1 \mathrm{~s} \text { are } \\
\text { the main formal training mean for } \\
\text { LC for the SMEs }\end{array}$ & $\begin{array}{l}\text { There should be a SME specific } \\
\text { LC maturity evaluation } \\
\text { framework }\end{array}$ \\
\hline $\begin{array}{l}\text { Some Lean techniques have been } \\
\text { applied fragmentarily }\end{array}$ & $\begin{array}{l}\text { SMEs have a little say on the } \\
\text { design at the moment. }\end{array}$ & & $\begin{array}{l}\text { Clients' specifications are too } \\
\text { rigid for the SMEs to deploy } \\
\text { innovation }\end{array}$ \\
\hline $\begin{array}{l}\text { Due to lack of a complete systems } \\
\text { thinking, some improvements made } \\
\text { by an SME can put extra workload } \\
\text { or pressure on others }\end{array}$ & $\begin{array}{l}\text { Clients' commercial teams could } \\
\text { present barriers before the SMEs }\end{array}$ & & $\begin{array}{l}\text { Business case for LC is essential } \\
\text { for the cash-sensitive SMEs }\end{array}$ \\
\hline $\begin{array}{l}\text { Application of some specific LC } \\
\text { techniques has not been } \\
\text { standardized enough }\end{array}$ & & & $\begin{array}{l}\text { LC has been rushed and pushed } \\
\text { from the top without a deeper } \\
\text { understanding }\end{array}$ \\
\hline $\begin{array}{l}\text { Some Lean techniques have been } \\
\text { applied fragmentarily }\end{array}$ & & & $\begin{array}{l}\text { Top-down imposition of LC is } \\
\text { common }\end{array}$ \\
\hline $\begin{array}{l}\text { Although not labelled as "Lean", the } \\
\text { SMEs have been already doing } \\
\text { process improvement (innovation) } \\
\text { in their daily activities. }\end{array}$ & & & $\begin{array}{l}\text { Knowledge retention for } \mathrm{LC} \text { is } \\
\text { problematic }\end{array}$ \\
\hline $\begin{array}{l}\text { SMEs currently give support to the } \\
\text { LC practices led by Tier } 1 \mathrm{~s}\end{array}$ & & & $\begin{array}{l}\text { There is no effectively working } \\
\text { SME innovation groups for LC }\end{array}$ \\
\hline $\begin{array}{l}\text { Use of BIM as an enabler is very } \\
\text { limited between the SMEs and their } \\
\text { clients }\end{array}$ & & & $\begin{array}{l}\text { Lack of real top management } \\
\text { buy-in for LC }\end{array}$ \\
\hline $\begin{array}{l}\text { SMEs struggle sparing enough time } \\
\text { and resources for LC }\end{array}$ & & & $\begin{array}{l}\text { Strategic alliances and supply- } \\
\text { chain integration are limited. }\end{array}$ \\
\hline & & & Risk aversion is too high for $\mathrm{LC}$ \\
\hline & & & $\begin{array}{l}\text { Current allocation of funds and } \\
\text { resources for LC in the supply } \\
\text { chain is generally not enough }\end{array}$ \\
\hline & & & $\begin{array}{l}\text { Current LC knowledge is } \\
\text { superficial and limited in the } \\
\text { supply chain. } \\
\text { Cooperation between the } \\
\text { organizations for LC is not } \\
\text { enough }\end{array}$ \\
\hline
\end{tabular}




\subsection{Future Directions for LC in the SMEs}

For the second research question, using the same classification groups, the future directions to disseminate LC further in the highways SMEs and across the supply chain were identified (see Table 2).

Table 2: Future directions for LC in the SMEs

\begin{tabular}{|c|c|c|c|}
\hline Process & Delivery & Training & Project Governance \\
\hline $\begin{array}{l}\text { Lean techniques should be better } \\
\text { extended to the operations phase. }\end{array}$ & $\begin{array}{l}\text { Forming long term alliances } \\
\text { with the Tier } 1 \mathrm{~s} \text { for different } \\
\text { projects }\end{array}$ & $\begin{array}{l}\text { SME clients should provide more } \\
\text { support for training and staff } \\
\text { employment in the SMEs }\end{array}$ & $\begin{array}{l}\text { SMEs would benefit from more direct contact } \\
\text { with HE }\end{array}$ \\
\hline $\begin{array}{l}\text { There is a need to improve the } \\
\text { use of BIM at the SMEs }\end{array}$ & $\begin{array}{l}\text { Earlier engagement with the } \\
\text { SMEs for projects }\end{array}$ & $\begin{array}{l}\text { SMEs should develop their in-house } \\
\text { training for LC. }\end{array}$ & $\begin{array}{l}\text { There is a need for the SMEs to improve their } \\
\text { current skills and expertise on LC }\end{array}$ \\
\hline $\begin{array}{l}\text { LC should be better extended to } \\
\text { the design phase. }\end{array}$ & $\begin{array}{l}\text { SMEs should have a say in the } \\
\text { design stage }\end{array}$ & $\begin{array}{l}\text { SMEs should better understand the } \\
\text { terms like value, waste and flow. }\end{array}$ & $\begin{array}{l}\text { SMEs should be shown the business case for } \\
\text { LC }\end{array}$ \\
\hline $\begin{array}{l}\text { Increased standardization in the } \\
\text { execution of specific LC } \\
\text { techniques in the supply chain }\end{array}$ & $\begin{array}{l}\text { Current lump-sum contracts } \\
\text { should be replaced with more } \\
\text { incentivizing contract } \\
\text { structures }\end{array}$ & $\begin{array}{l}\text { HE should take more initiative in } \\
\text { disseminating LC learning and } \\
\text { knowledge }\end{array}$ & $\begin{array}{l}\text { Overall organizational support and } \\
\text { commitment for LC should be increased in the } \\
\text { supply chain }\end{array}$ \\
\hline $\begin{array}{l}\text { Value based prioritizing is } \\
\text { necessary to implement some } \\
\text { Lean techniques in short } \\
\text { working windows }\end{array}$ & $\begin{array}{l}\text { Aligning commercial teams } \\
\text { with LC teams }\end{array}$ & $\begin{array}{l}\text { More academic collaboration } \\
\text { focusing on LC and the SMEs. }\end{array}$ & $\begin{array}{l}\text { There is a need for successful pilot LC } \\
\text { projects in the SMEs }\end{array}$ \\
\hline $\begin{array}{l}\text { Bottom-up practices for LC } \\
\text { should be given more } \\
\text { importance }\end{array}$ & $\begin{array}{l}\text { Longer term contracts } \\
\text { involving the Tier } 1 \mathrm{~s} \text { and } \\
\text { SMEs }\end{array}$ & $\begin{array}{l}\text { LC related lessons learned, best } \\
\text { practices, cases should be better } \\
\text { captured, retained and } \\
\text { communicated }\end{array}$ & $\begin{array}{l}\text { Increasing benchmarking efforts for LC } \\
\text { against other sectors and countries. }\end{array}$ \\
\hline \multirow[t]{8}{*}{$\begin{array}{l}\text { Improving systems thinking to } \\
\text { harmonize different LC efforts }\end{array}$} & $\begin{array}{l}\text { Current tendering mechanism } \\
\text { at the Tier 1s should better } \\
\text { support innovation (LC)- } \\
\text { share the risk and gain }\end{array}$ & $\begin{array}{l}\text { Current LC training mechanism } \\
\text { should be extended to cover more } \\
\text { advanced topics and be continuous }\end{array}$ & $\begin{array}{l}\text { Supporting the SMEs to form innovation } \\
\text { driving and sharing work groups }\end{array}$ \\
\hline & & $\begin{array}{l}\text { Going beyond the techniques, } \\
\text { training the SMEs for the strategic } \\
\text { deployment of LC }\end{array}$ & $\begin{array}{l}\text { There is a need for the SMEs to change their } \\
\text { work culture for LC for more information } \\
\text { share }\end{array}$ \\
\hline & & $\begin{array}{l}\text { Competencies and teachings of } \\
\text { Lean consultants should be better } \\
\text { monitored/ regulated. }\end{array}$ & $\begin{array}{l}\text { A strategic long-term focus for LC should be } \\
\text { developed at the SMEs }\end{array}$ \\
\hline & & $\begin{array}{l}\text { Joint training mechanisms for the } \\
\text { SMEs and Tier } 1 \text { s led by HE. } \\
\text { Raise the awareness on how } \\
\text { different techniques are linked to } \\
\text { each other and work as a complete } \\
\text { system. }\end{array}$ & $\begin{array}{l}\text { HE should expand the capacity of its LC } \\
\text { department. }\end{array}$ \\
\hline & & & $\begin{array}{l}\text { Tier 1s should embrace a supportive } \\
\text { management style with the SMEs }\end{array}$ \\
\hline & & & $\begin{array}{l}\text { Extended modularization and standardization } \\
\text { (off-site) in the design. }\end{array}$ \\
\hline & & & $\begin{array}{l}\text { Evaluation of objective third parties for LC } \\
\text { are needed in the supply chain }\end{array}$ \\
\hline & & & $\begin{array}{l}\text { Coordination and collaboration in the supply } \\
\text { chain should be increased to make innovations }\end{array}$ \\
\hline
\end{tabular}




\section{Discussion}

The initial findings as to the current condition of LC mostly validated the literature; lack of resources for LC deployments in the SMEs, conventional project delivery systems not incentivizing LC or innovation, need for creating the business case for LC in the SMEs, fragmentation and short-term contractual relations, lack of support for and focus on the SMEs. However, there are also more sector specific parameters like short on-site working windows in the highways sector, and fragmented and unstandardized LC techniques (i.e. the Last Planner, Visual Management). Also, although not labelled as LC, the interviews highlighted that the SMEs do ad-hoc process improvement and innovation in their operations. It was identified that in the highways sector, where the deployment of LC is relatively new, the same concerns that were identified 20 years ago still exist.

For the future action points, there are responsibility items for all the supply chain actors (e.g. HE, the SMEs and large companies). The gist of the findings for the future is to engage with the SMEs directly, to support them with necessary resources and incentivizing project delivery mechanisms, and to devise a continuous training plan going beyond the basics and specifically targeting the SMEs. Also, demonstrating the business case for LC through pilot LC projects, and effectively capturing and disseminating the LC knowledge seem necessary. Training and project governance related findings come to the fore.

\section{CONCLUSION}

SMEs often constitute the largest group in construction supply chains. However, LC deployment discussions have rarely focused on SMEs to date with sector-level analyses being even scarcer. For an extended dissemination and deployment of LC across construction supply chains in different sectors, it is essential to gain a better understanding of the issue from the SMEs' point of view.

This paper summarized the initial findings of a research effort supported by HE and aimed at understanding the current condition of and future directions for LC at the SMEs in England's highways supply chain. After the analysis of the findings from the survey, which was prepared based on the interview findings outlined in this paper, a more complete understanding of LC in the SMEs will be achieved. Alongside validating the interview findings, the statistical analysis of the survey study will help rank the relevance of each current condition point (the first research question) and the importance of each future directions (the second research question) from different supply chain actors' perspectives (e.g. the SMEs, Tier 1s and large Tier 2s) for prioritization.

\section{REFERENCES}

Alves, T.D.C.L., Barros Neto, J.D.P., Heineck, L.F., Pereira, P.E. and Kemmer, S.L. (2009). Incentives and Innovation to Sustain Lean Construction Implementation. In Proceedings of the $19^{\text {th }}$ Annual IGLC Conference, Lima, Peru.

Alves, T.D.C.L., Milberg, C. and Walsh, K.D. (2012). Exploring Lean Construction Practice, Research, and Education. Engineering, Construction and Architectural Management, 19(5), pp. 512-525.

Barros Neto, J.D.P. and Alves, T.D.C.L. (2007). Strategic Issues in Lean Construction Implementation. In Proceedings of the $15^{\text {th }}$ Annual IGLC Conference, Michigan, USA. 
Briscoe, G., Dainty, A.R. and Millett, S. (2001). Construction Supply Chain Partnerships: Skills, Knowledge and Attitudinal Requirements. European Journal of Purchasing \& Supply Management, 7(4), pp.243-255.

Dainty, A.R., Briscoe, G.H. and Millett, S.J. (2001). Subcontractor Perspectives on Supply Chain Alliances. Construction Management \& Economics, 19(8), pp.841-848.

Drysdale, D. (2013). Introducing Lean Improvement into the UK Highways Agency Supply Chain. In Proceedings of the 21st Annual IGLC Conference, Fortaleza, Brazil.

Ferng, J. and Price, A.D. (2005). An Exploration of the Synergies between Six Sigma, Total Quality Management, Lean Construction and Sustainable Construction. International Journal of Six Sigma and Competitive Advantage, 1(2), pp.167-187.

Green, S.D. (1999). The Missing Arguments of Lean Construction. Construction Management \& Economics, 17(2), pp.133-137.

Green, S.D. and May, S. (2005). The Missing Arguments of Lean Construction. Building Research \& Innovation, 33(6), pp.498-511.

Miller, C.J., Packham, G.A. and Thomas, B.C. (2002). Harmonization between Main Contractors and Subcontractors: A Prerequisite for Lean Construction? Journal of Construction Research, 3(1), pp.67-82.

Morton, R. and Ross, A. (2008). Construction UK: Introduction to the industry. WileyBlackwell.

Ogunbiyi, O., Goulding, J.S., and Oladapo, A. (2014). An Empirical Study of the Impact of Lean Construction Techniques on Sustainable Construction in the UK. Construction innovation, 14(1), pp. 88-107. 